\title{
IMPORTANCE OF GEOTECHNICS IN TODAY'S AND FUTURE CIVIL ENGINEERING - Public image, risks and responsibilities and future aspects of civil/geotechnical engineering
}

\author{
Heinz Brandl \\ Vienna University of Technology, Em.O.Univ.-Prof. Dipl.-Ing. Dr. techn. Dr.h.c.mult.
}

\begin{abstract}
This contribution is dedicated to the public image of the civil engineer and geotechnical engineer, respectively, seen from an ethical and philosophical point of view. Discrepancies between professional opinions, the gap between theory and practice, pros and cons of codes or regulations, and the lifelong learning society are discussed on the basis of the author's nearly fifty years of comprehensive professional experience. Furthermore, the environmental challenge to civil/geotechnical engineering due to climate change and global increase in population is emphasized. Finally, the younger engineering generation's prospects in the future are addressed and recommendations are given.
\end{abstract}

Key words: geotechnical engineer; engineering ethics

\section{VAŽNOST GEOTEHNIKE U DANAŠNJEM I BUDUĆEM INŽENJERSTVU - javni imidž, rizici, odgovornosti i aspekti građevinarstva/geotehnike u budućnosti}

Sažetak: Ovaj rad je posvećen javnom ugledu građevinskog i geotehničkog inženjera, gledano s etičke i filozofske točke gledišta. Razlike između stručnih mišljenja, raskorak između teorije i prakse, prednosti i mane norma ili propisa te cjeloživotnog učenja društva, diskutirani su na temelju autorovog, gotovo pedesetgodišnjeg radnog iskustva u struci. Nadalje, u radu je posebno naglašen ekološki izazov za građevinsko/geotehničko inženjerstvo zbog klimatskih promjena i ukupnog porasta stanovništva. Također se razmatraju i mogućnosti uspjeha mlađih naraštaja inženjera te daju neke preporuke.

Ključne riječi: inženjer geotehnike; inženjerska etika 


\section{Public opinion and reality}

We live in the age of high tech. Though engineering stands at centre stage becoming the key to survival, civil engineering is a much misunderstood and widely underestimated profession (Figure 1). It is a melancholy paradox: in its moment of ascendance and severely needed by society, civil engineering is frequently faced with the trivialization of its purpose and the debasement of its practice.

In the social system of ancient Egypt, civil engineers (especially hydro and structural engineers) ranked directly below the viziers (and the God-King), and were thus in a position equal to governors of the provinces. Architects, painters and artists were subordinate to them (Figure 2). But these times are long gone.

Most individuals, living in a modern industrial state, are not aware how much it is the achievement of civil engineering that so many people can live comfortable lives in such relatively small areas. For the basic needs of society, civil engineers build water supply and sewage facilities; they construct apartment and office buildings, factories, as well as storage facilities and silos. For the distribution of goods they build roads and railways, waterways, market halls, department stores and supermarkets. For the education of children they construct all kinds of schools, and, to an ever increasing extent, trade schools, colleges and universities for the professional education and training, because more and more people strive for higher education to enrich their lives. Civil engineers erect (drinking) water supply systems, irrigation systems and the facilities to obtain natural resources, they build power plants for energy generation, hospitals where people hope to be cured, sport facilities for bodily fitness -as well as sewage removal systems, waste water purification plants and refuse deposits in order for society not to be suffocated by the waste created by industrial production and by every-day-living, and in order to prevent irreparable damage to the environment. Furthermore, civil- and geotechnical engineers minimize natural hazards (e.g. by landslide stabilization, flood protection, avalanche and mudflow protection, design of earthquake resistant structures, etc.).

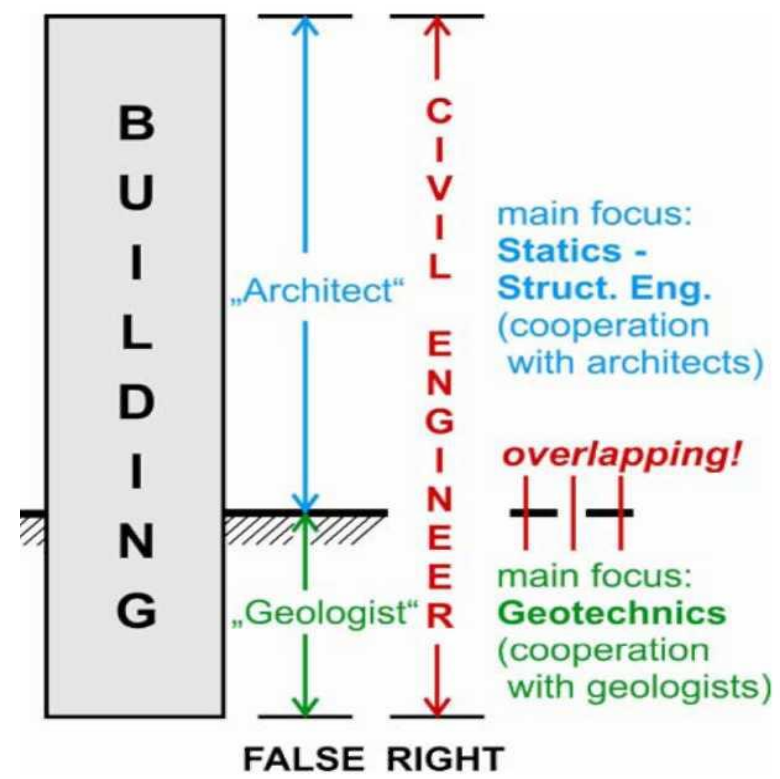

Figure 1 - Where is Civil Engineering? Hidden between architects and geologists? Overlapping interaction and cooperation are essential

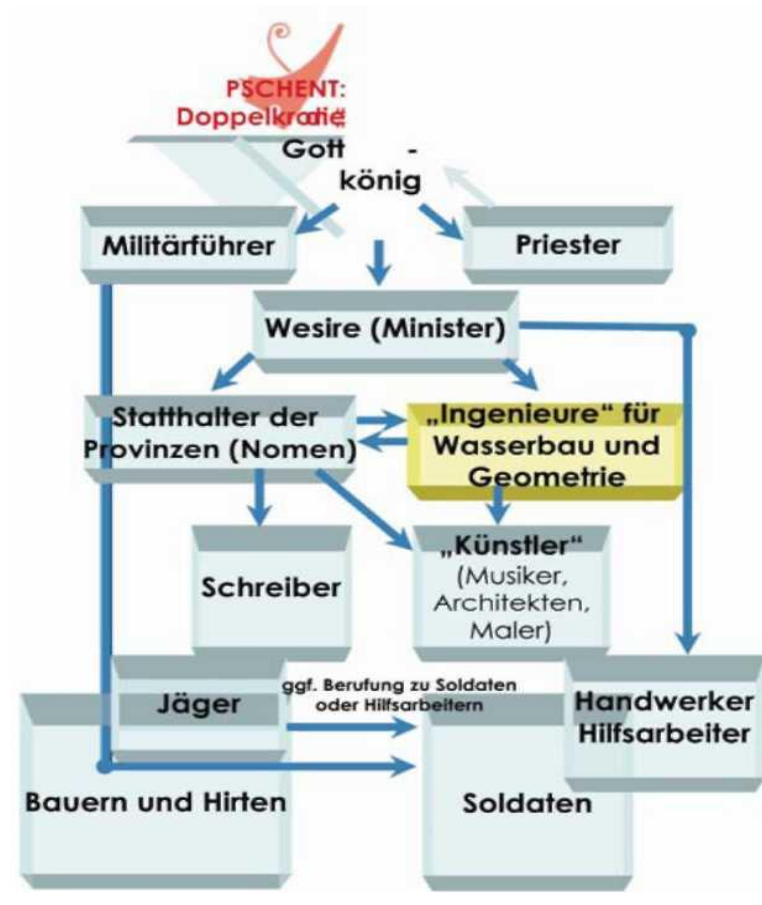

Figure 2 - In the social system of ancient Egypt civil engineers (hydro engineers) ranked directly below the viziers (and the God King) in a position equal to governors of provinces 
Very few people recognize that it was primarily civil/geotechnical engineering that made it possible that the average life expectancy of men in the industrialized countries increased so dramatically during the past 100 to 125 years: In former centuries drinking water was often contaminated and full of bacteria. This foul water and the improper removal of waste caused terrible epidemics (e.g. cholera, typhoid fever, dysentery), which killed millions of people in Europe alone. From this point of view, it is the merit of civil/geotechnical engineering to have saved more lives than medicine by providing the means for clean drinking water supply and for the proper disposal of liquid and solid waste (Figure 3). The first public Vienna drinking water system, for instance, was constructed in the years 1870-1873, and it has been supplying the population with 470 million litres of high quality water per day ever since. The total length of the pipes from the headwaters region in the mountains to the reservoirs in Vienna is $3,100 \mathrm{~km}$.

Most people understand construction as constructing houses or buildings. This misconception had made civil engineering a very small term in public opinion. But actually, construction is one of the biggest industries worldwide, in India for instance even number two behind agriculture. And it is far beyond the film industry, which takes at least one full page in every newspaper describing its legends every day.
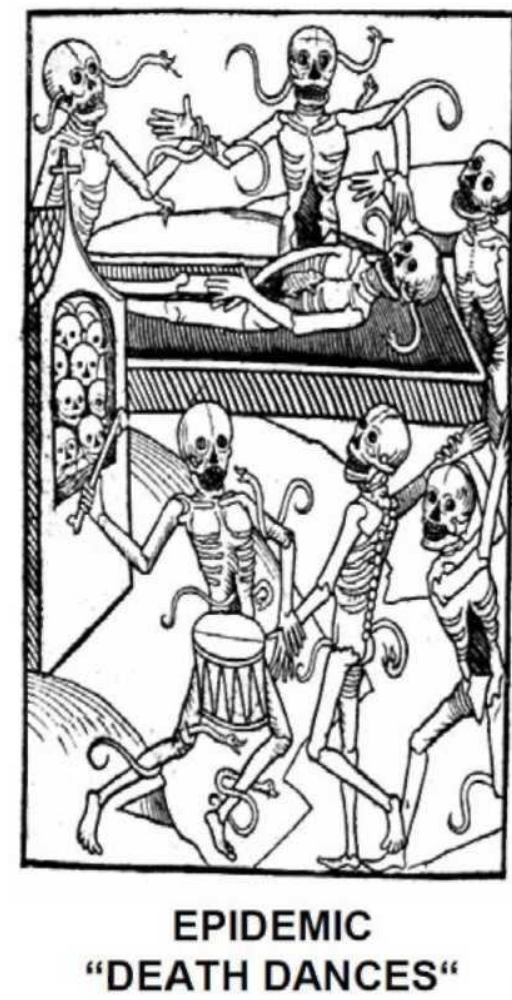

Cholera-Epidemic (Hamburg 1892)

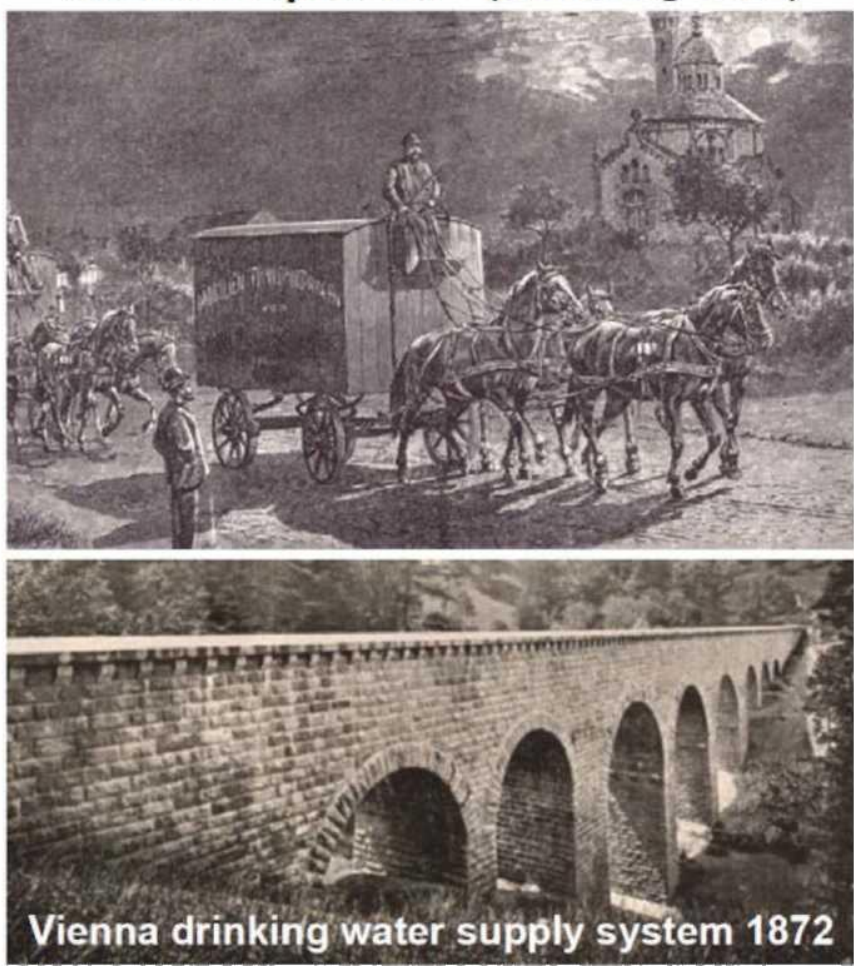

Figure 3 - Contribution of civil engineering / geotechnical engineering to increase human life expectancy through clean drinking water. Contrary to Hamburg its twin city part Altona had in 1892 already a modern drinking water supply and, therefore, remained free from the Cholera epidemic. Vienna had this already in 1872 (right, below)

It was through dams, not gold that California became the equivalent of the world's seventh richest country: Dams have turned the arid Central Valley into an agricultural supermarket to the world. Dams quench the thirst of coastal cities from San Diego to San Francisco with billions of gallons of fresh water annually. Dams let Sacramento escape regular devastating floods. And above all, dams power the states aerospace, microchip, film or "dotcom" industries with an average $40 \mathrm{BMWh}$ of electricity: more than coal, oil, geothermal waste, wind and solar energy sources combined (Asmal 2000).

The main reason for this discrepancy with regard to our profession is that most achievements are taken for granted. They simply work and civil or geotechnical engineers are not spectacular enough for the media. 
Attention is paid more or less only in the case of failures or building collapse, according to the media's principle "only bad news is good news".

On the other hand it is our fault that the public is not informed about outstanding achievements of our profession, e.g. construction of 10-lane underground expressways in urban areas and soft soil, structures in sliding slopes and earthquake zones, etc.: Engineers do not talk very much about the work that they have done, and they are rather reserved towards media people.

It is hardly known that the first fully-working, program-controlled, electromechanical digital computer in the world (already with 2000 relies) was invented in 1941 by a civil engineer (the German K. Zuse, 1910-1995), who in 1955 also invented the first electronic device to rationalize and accelerate the many comprehensive calculations he had to perform in structural and geotechnical engineering.

The Scottish bacteriologist Sir Alexander Fleming (1881-1955), for instance, is well known worldwide (Nobel Prize for development of penicillin), but only few persons have heard about the Canadian civil engineer Sir Sanford Fleming (1827-1915) who coordinated the development of railways, telegraph, and standard time zones.

The American civil engineer (and medical doctor) Andrew Taylor Still (1828-1917) founded the osteopathy, an alternative medical treatment using only the hands.

The German civil engineer Johann Tschauner (1908-1974) became a pioneer of rocket and space technology and astrodynamics.

Also very few people know how much civil engineering contributes to modern medicine: Hydraulics is not only used in waterpower technology and for designing drinking water supply systems and sewage systems but increasingly also for the calculation/assessment of the streaming behavior in blood vessels (especially in the vicinity of bypasses). Statics contributes significantly to the medical understanding of stress-strain behavior of the human (or animal) skeleton and muscle system - thus becoming an important factor for difficult operations, rehabilitation, for prostheses, etc. Screws made of bone material are used in the oral and maxillo-facial surgery. Statics and strength of material sciences are even helpful in dermatology: For example, taking into account the major and minor principal stress directions of a local skin area during skin operations helps to minimize scar formation later. The special course "Biomedical Engineering" at the Vienna University of Technology underlines this cooperation between civil engineering and medicine.

The main task of the building industry (including geotechnical and environmental engineering) is not only the construction of new structures, but also the maintenance, and finally the repair of those old damages, which have been caused within the last decades by our industrial "squandering society" - partly through ignorance and partly through lack of knowledge.

For nearly a century the "men of technology" had been considered the personification of progress. The historian Thomas Buckle, for instance, wrote with enthusiasm: "The railway did more to bring people together, than all philosophers, poets and prophets before". This glorification of technology has now, in many cases, turned into just the opposite, sometimes even to a "Techno-phobia". The present doubts and uncertainties are expressed by Peter Ustinov: "The last voice to be heard before the globe exploded was that of an expert saying that this would be technologically impossible."

Anti-technology fanatics and unrealistic environmentalists have now even created the rude term "technofascism" which comprises the whole field of techniques. But they forget that modern life depends entirely on technology, and this will increase more and more as time goes on. Technology critics would, no doubt, ask for remote surgery if this advanced technique could save their lives. And most of those who condemn modern production nevertheless are consumers of those products.

From the "warm bed" of an affluent, industrialized society it is relatively simple now to globally criticize the enormous achievements of technology, which would not even have been possible in dreams 100 years ago. This criticism is not voiced by the generally practical and realistic silent majority, but by some thoughtless or even untrustworthy media people, opportunistic politicians, narrow-minded idealists who do not understand the paramount connections, and finally by dreamers, pseudo intellectuals, and image neurotics. "Experts" who, more or less, oppose any new project without proposing alternatives are like dentists who bore holes into the teeth but don't fill them.

The civil and geotechnical engineer is, and always has been, primarily an executive organ (but not an executive "slave"). Not he should be criticized but those clients, official or private, who wanted to have a certain project realized. Until a few years ago, almost every mayor of a city or a village fought like a lion to have as many broad streets built as possible, because that was considered modern and a sign of progress. Now, the same 
individuals complain of the disadvantages of increasing traffic. Can this development be blamed on the civil engineer? Definitely not!

We run risks. Most of the time we ignore them; sometimes we stop and decide how to deal with them. That's life. Risks arise in sports, in business, in personal relationships; they are present in the laboratory, in technology, in medicine, on construction sites, in traffic, in political calculations, everywhere (Figure 4). Acting individually, we often prefer to gain some benefit by accepting some danger. Acting collectively, we make similar trade-offs (Nicholas, 2000).
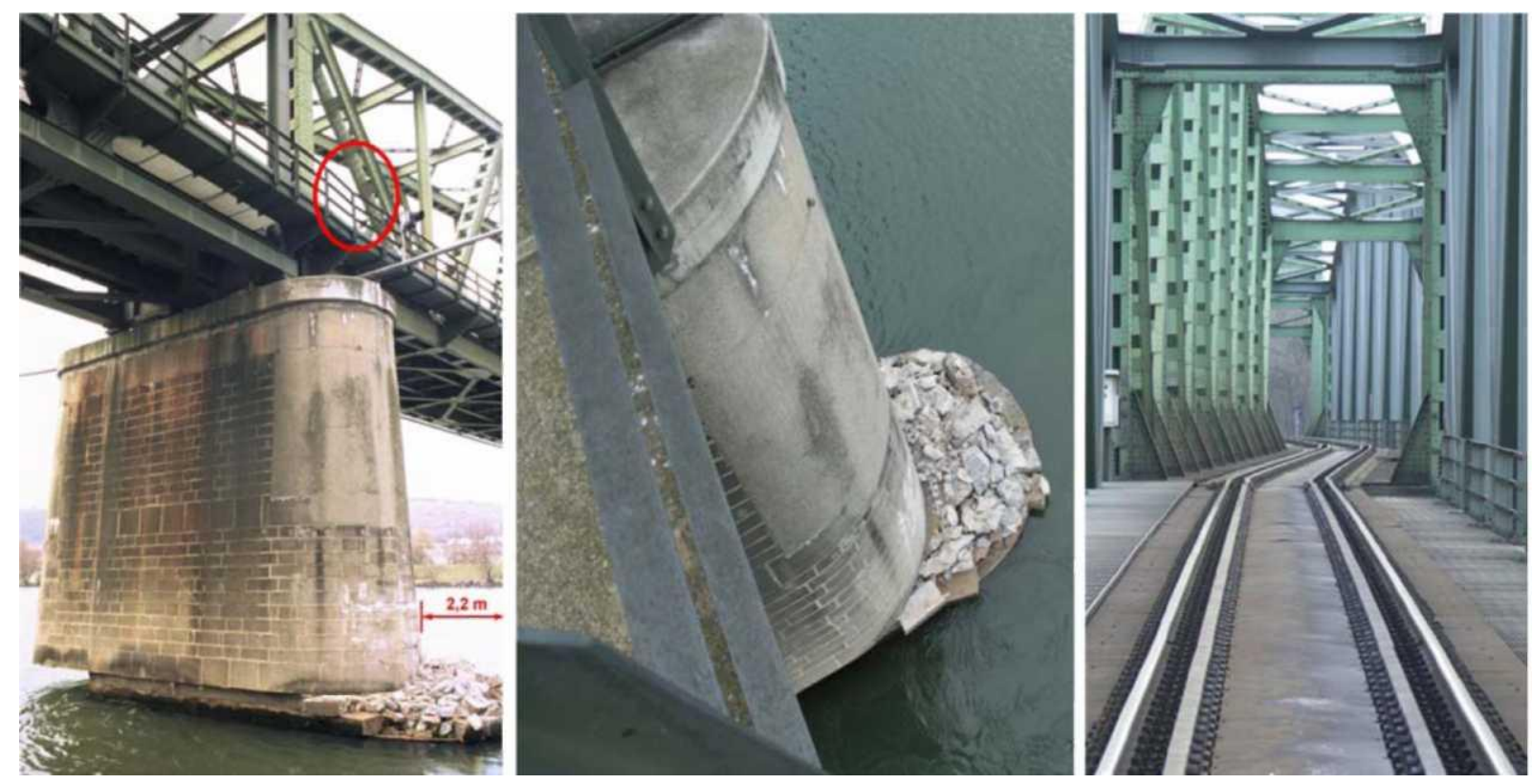

\section{Figure 4 - Ship impact at a main pier of a railway bridge crossing the river Danube. Toe zone of the pier sheared off by $2.2 \mathrm{~m}$; steel girders show multiple buckling}

When society must assess risks, and those risks can be clarified, at least in part, by science, technology or mathematics, the responsibility of the research community seems to be "clear and complete". But that is not always so easy.

People frequently expect a so-called zero-risk or at least that today's risks must be manageable. The first demand is absolutely unrealistic; the second one can only be partly achieved. Risk level, risk assessment and risk management depend on numerous interacting factors and on the specific fields, as medicine, transportation engineering, mechanical engineering, civil engineering, etc.

Civil engineering, especially geotechnical engineering, involves higher professional risks than most of the other technical fields. Calculated risk and residual risk have to be well balanced, whereby a central question remains: "How safe is safe enough?" Failures can occur in spite of detailed ground investigation, sophisticated calculation, site supervision and monitoring - they are inevitable because of the complex nature of ground and groundwater. Nevertheless, the public opinion is very critical towards this branch of engineering, and "building scandal" or "construction scandal" is a term easily used by the mass media for headlines. Moreover, engineers, as viewed by the public, should exclude every risk (even if unidentifiable).

On the other hand, the public has more or less got used to traffic accidents killing thousands of people per month worldwide. There is a great difference in the evaluation of car accidents on the one hand and other accidents on the other. The car has obviously become today's "idol" or "golden calf which consequently involves the public acceptance of high risks to life and health, while accidents e.g. caused by a failure in the road structure, by uneven pavement on expressways, or by a bridge collapse (e.g. due to scouring) are condemned as almost criminal acts. Consequently, it should be emphasized that a so-called $100 \%$-safety cannot be obtained in many cases of geotechnical engineering (e.g. landslides, earthquakes). And this must be accepted by

- the public,

- politicians and other decision makers, 
- $\quad$ and by lawyers.

Several clients and politicians have been quoted as saying that they would like some day to meet an engineering geologist or geotechnical engineer who is one-armed - so that he will not be able to say "on the other hand". This rather feeble witticism reflects on all too prevalent impatience with uncertainty. We crave for clear answers, but ground is an uncertain material. Hence, it is one of the greatest challenges in geotechnics to come up with a design or an answer when no clear-cut, ideal solution exists.
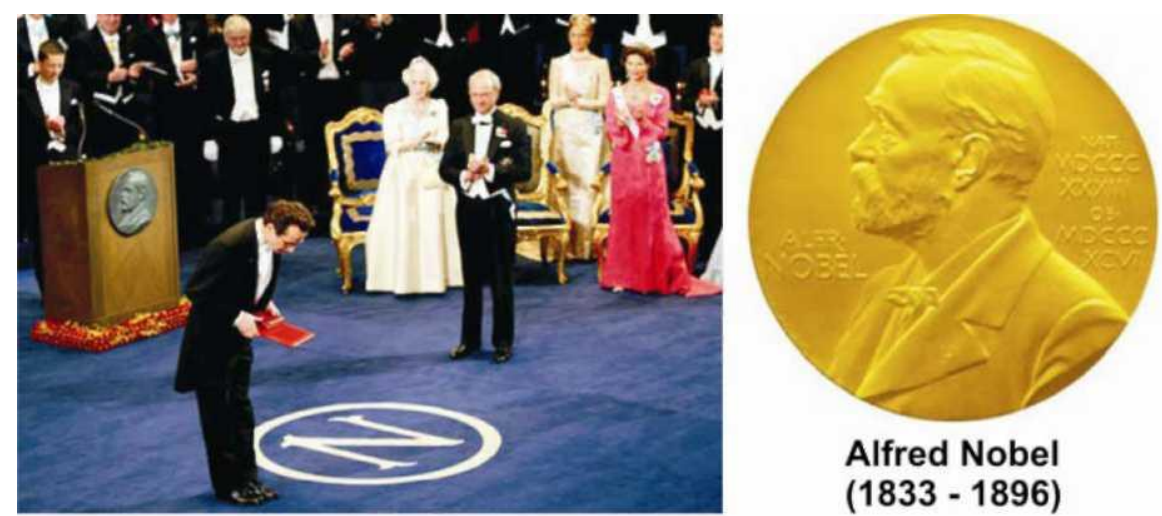

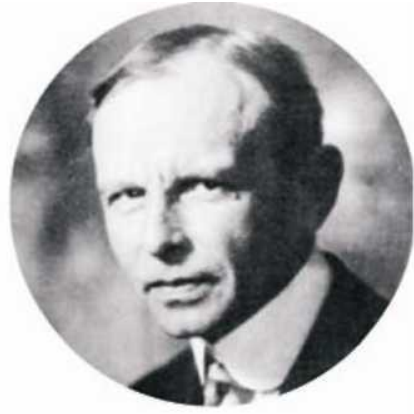

Karl v. Terzaghi

(1883 - 1963)

Figure 5 - There is no Nobel Prize for Engineering Sciences

Geotechnical engineering achievements or scientific work cannot be evaluated by prizes as in case of architectural competitions. Though originally very laudable and productive, the rating business has been in many cases taken to ludicrous extremes (e.g. "best" dentist or pizza parlor of the town). It may be explained by the US syndrome for ratings and rankings, which results from the super-competitive urges of its population. But what shall all this rating/ranking accomplish in geotechnical engineering? An objective evaluation is practically impossible and makes no sense. So please, let us stay away from producing rankings (Dunnicliff 2000).

It seems, that even normal ranking alone is not sufficient any more. The term "excellence" has become increasingly over-stressed and overused. Institutions, universities, companies, etc. all are offering special fields of "excellence", and the peak is the Nobel Prize. However, for engineering sciences (as well as for architects) no Nobel Prize exists, though persons like Karl Terzaghi or Nikolaus Tesla certainly would have deserved this outstanding award (Figure 5).
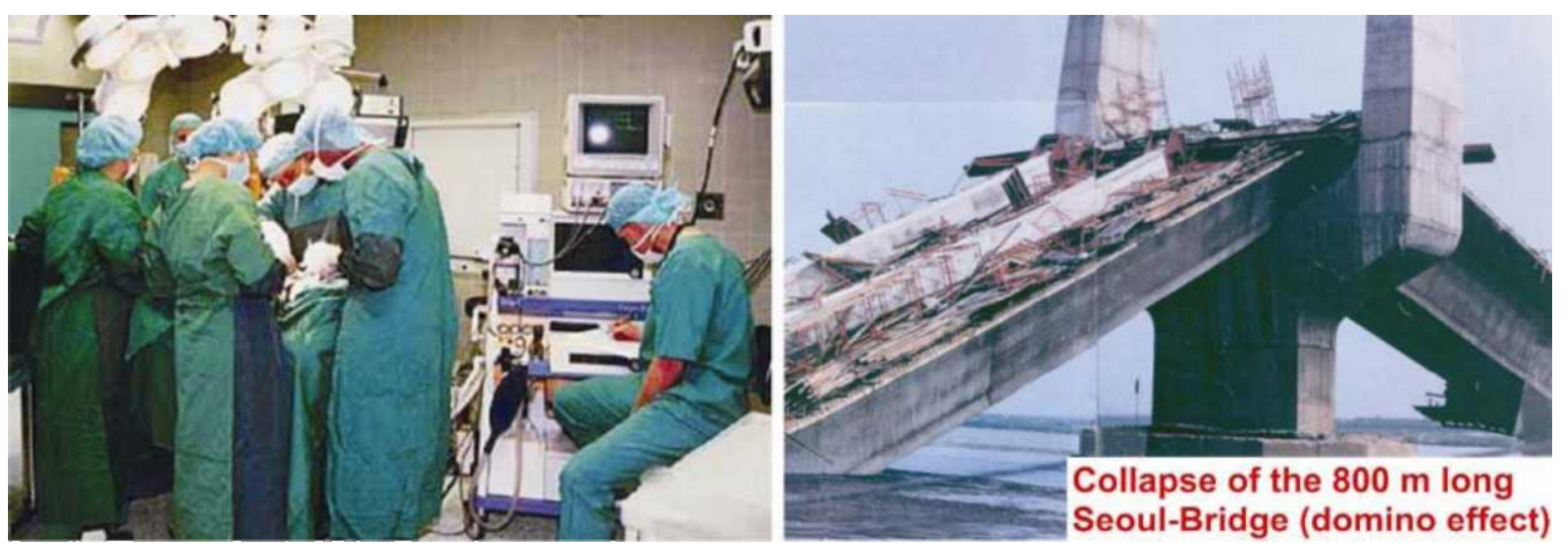

Figure 6 - Medicine and (geotechnical) engineering: Similarities (Observational Method), cooperation (e.g. statics) and differences (number of "failures"; image in the public opinion)

Despite all efforts to improve the image of the civil engineer, it will always be below that of the colleagues of medicine, physics, or chemistry - because high-tech surgery, for instance, directly saves lives, and flights to the 
moon are just more spectacular than even the most impressive structures. Especially disadvantaged in this respect are we, the geotechnical engineers. It is said that surgeons cover up their mistakes by burying them; in our work the successes are buried and hidden below the ground surface, upon which the architects put their "visible" structures and are praised for them. Our names are only mentioned if something goes wrong. This should not frustrate us too much, because geotechnical engineers work with the contents and not with the image.

Coming back to the comparison geotechnical/civil engineering and medicine (Figure 6): Recent medical statistics disclosed that in Great Britain about 40.000 people annually lose their life because of medical mistakes. The same number is known from Italian hospitals, whereby organizing problems and defect equipment, and less medical mistakes play a role. In Germany, about 25.000 patients die because of wrong treatment or unsuccessful surgery. In addition, about 300.000 patients survive but suffer permanently from severe treatment mistakes. Imagine, if geotechnical engineers designed and constructed in such a way that, let's say, 10 people annually would lose their life in each of these or other industrialized countries. The public would rip them apart. Nevertheless, the doctors still remain the Gods in white, while the engineers are frequently looked down upon as technocrats. But anti-technology fanatics forget that modern life depends entirely on technology, and this will increase more and more as time goes on.

New technological approaches to sustainable global development are required - not just better policies. Technology is the most promising way out of a lot of seemingly irreconcilable goals associated with bringing the world's impoverished regions into a certain economic boom. But until now global development efforts have been hampered by the failure to mobilize science and technology adequately. In this connection geotechnical and civil engineering could contribute essentially (e.g. infrastructure, irrigation, clean and renewable energy supply, urban ecology, resources and waste management, disaster mitigation). The challenge for all of us is to demonstrate that, as civil engineers, we can improve the quality of life in an equitable and lasting way.

\section{Discrepancies between professional opinions}

A close co-operation of experts of various disciplines is wanted and definitely necessary (e.g. geology, geotechnics, structural engineering, hydraulics, physics, chemistry, etc.). But it becomes ethically questionable when some specialists let themselves drift into fields of expertise other than their own, and when they think they would be qualified to act as commentators or even experts, despite their lack of specific knowledge. The grey zone of "half knowledge" of so-called experts is frequently rather wide - and, unfortunately, people mostly tend to believe the wrong half (Figure 7). In addition, more and more self-appointed "experts" appear on the scene, most of them contributing to the undermining of the decision makers' judgment, sometimes even leading to their total confusion.

Experts who are under the pressure of one of the parties in a hearing, or who are otherwise subjected to directives, have to be considered biased. There is also a certain obsession for image building or the striving for the receipt of contracts and jobs, which sometimes influence expert opinions in a questionable way. Whoever has observed the performance of such experts in meetings or hearings will be able to understand the reactions of distrustful or confused politicians - especially in environmental and transportation engineering and in urban design. Sometimes it is not clear "if such experts help to solve a problem or if they are themselves the problem".

Many experts believe in the philosophy of "he who pays the piper calls the tune". This attitude - which can be found in almost any field - might bring short-term success, but in the long run it represents a dangerous boomerang: Both parties lose credibility. Experts who knowingly write tendentious reports in the interest of their client are not legally liable (as long as no criminal offence exists). They can be compared to lawyers who primarily have their client's interest in mind. The lawyer defends his client by over-stressing the positive aspects and omitting the negative ones. In contrary, an engineer must take an equal account of both sides, otherwise he will be considered as a "one-sided, tendentious expert" and lose professional reputation. To sum up, the engineer has definitely to look for the truth, which is not necessarily the duty of the lawyer.

It can certainly happen within the realm of the sciences that experts of unquestionable integrity are of different opinion on special points. Diversity of opinion of experts is hardly new - on the contrary, such discrepancies have always been a spark for further development and often have bred innovation. They should therefore not necessarily be regarded as negative. But there obviously is cause for concern if the public believes that for each expert opinion there might exist (or be ordered) a contradictory opinion by another expert. Typical 
examples throughout the industrialized world are environmental impact assessments or the site evaluation and selection for a new waste disposal facility.

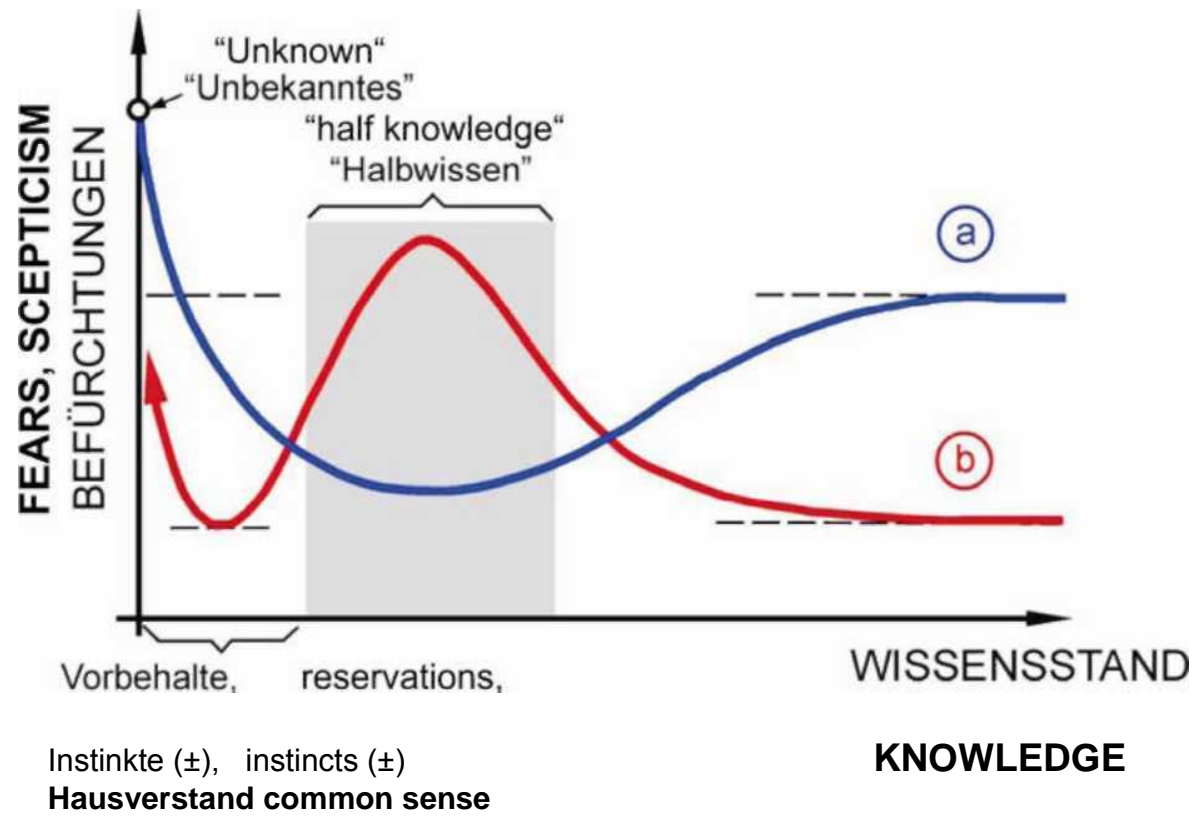

Figure 7 - Fears, scepticism, etc. of people versus their volume of knowledge and the grey zone of "half knowledge" (schematic): Curve $a=$ usual case Curve $b=$ special case regarding design and public acceptance of waste deposits or waste treatment facilities and of large scale projects (highways, power plants, high voltage lines, etc.)

Experience tells us that the largest source of claims and disputes in the civil engineering field is in the ground. Nevertheless, an alarmingly large percentage of ground engineering is done by non-geotechnical engineers or by geologists with insufficient civil engineering background.

What is very often not realized is that - as in most other aspects of life - there exists a difference in the quality of professional opinions and qualifications. Equal (professional) levels - in a democratic or legal sense can hardly be found in the case of totally contradictory statements. Actually, experience has shown that highly qualified experts usually arrive at rather similar opinions - or they are at least able to agree on a joint declaration. Huge discrepancies are nearly always based on big differences in the qualification of the experts. Friedrich Engels stated already in 1878 "There is just no democratic forum for scientific work".

Especially dangerous are those "experts" who don't know what they don't know. Incompetent persons are sometimes like noisy sparrows: they appear in swarms and drive away the song-birds.

The decision makers, especially the politicians, thus have to have the courage to stand by the opinions of high-level professional experts - and should ignore possible "counter-opinions" from biased, image-neurotic, or self-appointed experts. Here, the interest of the community has to be put before the egoistic interests of individuals.

"Experts" or groups hindering or even preventing the construction of buildings, which are required for the infrastructure of modern society (e.g. highways, railways, power plants, waste disposal facilities) should be called to account for their egoistic or fundamental, or even anarchistic activities. Most of the time such people only discuss what is not possible, not justifiable, not allowable, not appropriate, not functional, etc. Positive, constructive suggestions and the (co-operative) search for feasible, realistic solutions are pushed into the background. This can result in a feeling of uncertainty on the part of the politicians, can diminish their ability to make decisions and sometimes even lead to their total resignation.

The expert, for his part, will have to get used to accept and allow doubts that are expressed with regard to his qualification, his professional knowledge and the correctness of his opinion, and not consider them as lèse majesté. Distrust about the expert's objectivity should be accepted by him with philosophical calmness. 
Moreover, the expert increasingly needs inexhaustible patience, for instance with those neighbours of construction projects who lose all objectivity purely because of their contradictory standpoint and personal interest. A typical example is the "not-in-my-backyard" syndrome which can be found so often in the siting of new waste management facilities (landfills, incineration plants). All too often, the issues opposing such siting are nontechnical, e.g. they are political, social, conceptual, emotional, etc. When considering a new or virgin site (also called "Greenfield" site), the situation is heightened to the point where technical logic is often completely left out of the decision making process. Moreover, there is a wide emotional discrepancy in the public tolerance regarding contamination by public traffic or landfills (Figure 8). Only few persons would abstain from driving a car.
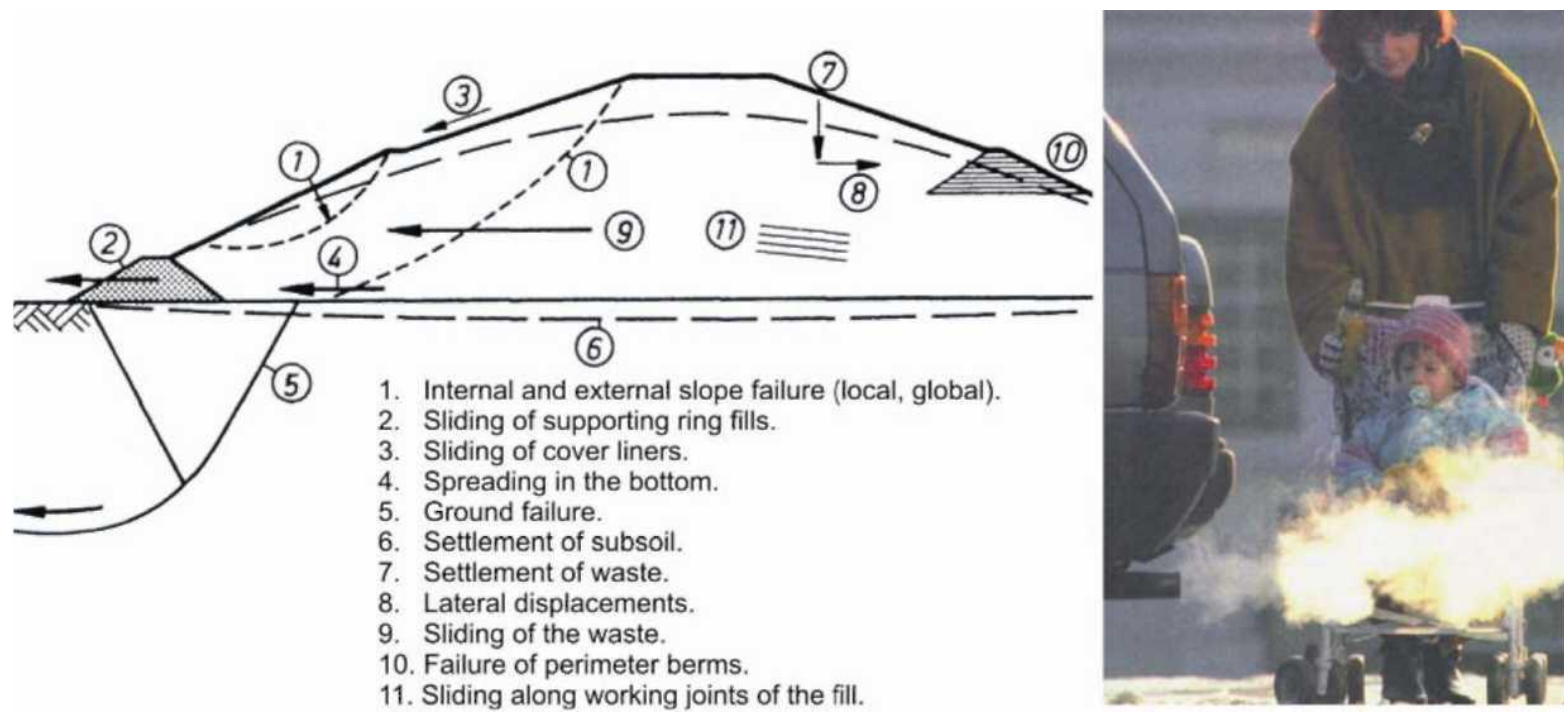

Figure 8 - Example from environmental geotechnics: Prove of ultimate limit states and serviceability for municipal waste deposits. Widely different contradictory tolerance regarding contamination through landfills or public traffic

To sum up, that type of expert is needed "who gains his self-confidence and his authority from the quality of his expert opinion and not merely from his function and position". Finally, there is a relation between advanced technology and civilization; nevertheless an advanced civilization may be uncultured. Hence, striving for technology, civilization and culture as an interacting trinity or a single entity should be the goal of education and professional practice. The civil engineer should be a civilized engineer - and cultured too.

\section{Engineering ethics}

In many countries, the construction industry has been exposed to severe criticism as a result of poor business behavior, malpractice, or even corruption. Illegal actions cannot be excused under any circumstances. For instance, price-fixing and bribery are against the law in most countries. In different cultures the lines between the acceptable and unacceptable are drawn differently, but these differences are "marginal rather than fundamental". If "gift giving" involves secrecy it is unacceptable. In 1999, 34 OECD countries signed the Anti-Bribery Convention making it a criminal offence to bribe foreign officials. So, why should the building industry take the law any less seriously than other industries?

The time is right for the engineering profession and the construction industry to take a public stance against corruption. Corruption has - among other things - the effect of lessening the amount of capital invested in locations where infrastructure is often desperately needed.

Questionable and even unethical are arrangements where consultants or designers are rewarded with success fees if they achieve savings in construction costs by recommending lesser or poorer materials. This will cause a decrease in quality and an inexcusable increase in risks. Unfortunately, the different results gained from 
different theories and assumptions facilitate such negative practices. After all, buildings, especially underground structures or embankments, etc. appear "stable" to the eye, no matter if they exhibit a "real" safety factor for instance of $F=1.05$ or of $F=1.50$.

Making money and high moral standards are in principle not contradictory. But price competition at the expense of technical quality should be avoided.

Natural uncertainties are unavoidable in geotechnical engineering, but safety standards should not be reduced additionally by low quality or brutal competition. In this connection the British social reformer John Ruskin (1819-1900) should be quoted. It might be of interest for clients, authorities and contractors alike:

"There exists hardly anything in this world that could not be produced in a lower quality and be sold at a lower price - and people who orientate themselves on the price only are the natural prey for such practices. It is not clever to pay too much, but it is even less clever to pay too little. When you pay too much, you lose some money - that's all. When, on the other hand, you pay too little, you sometimes lose everything, because the purchased object cannot fulfill its intended purpose. The law of economics does not allow to obtain big value for little money. If you take the lowest offer, you have to add something for the risk you take. And if you do that, you also have enough money to pay for something better than the lowest offer."

Lacking or even missing ground investigation in the design phase and/or during the construction phase is certainly the wrong way to save money. Numerous case histories have confirmed J. Ruskin's philosophy again and again (e.g. Figures 9 and 10).
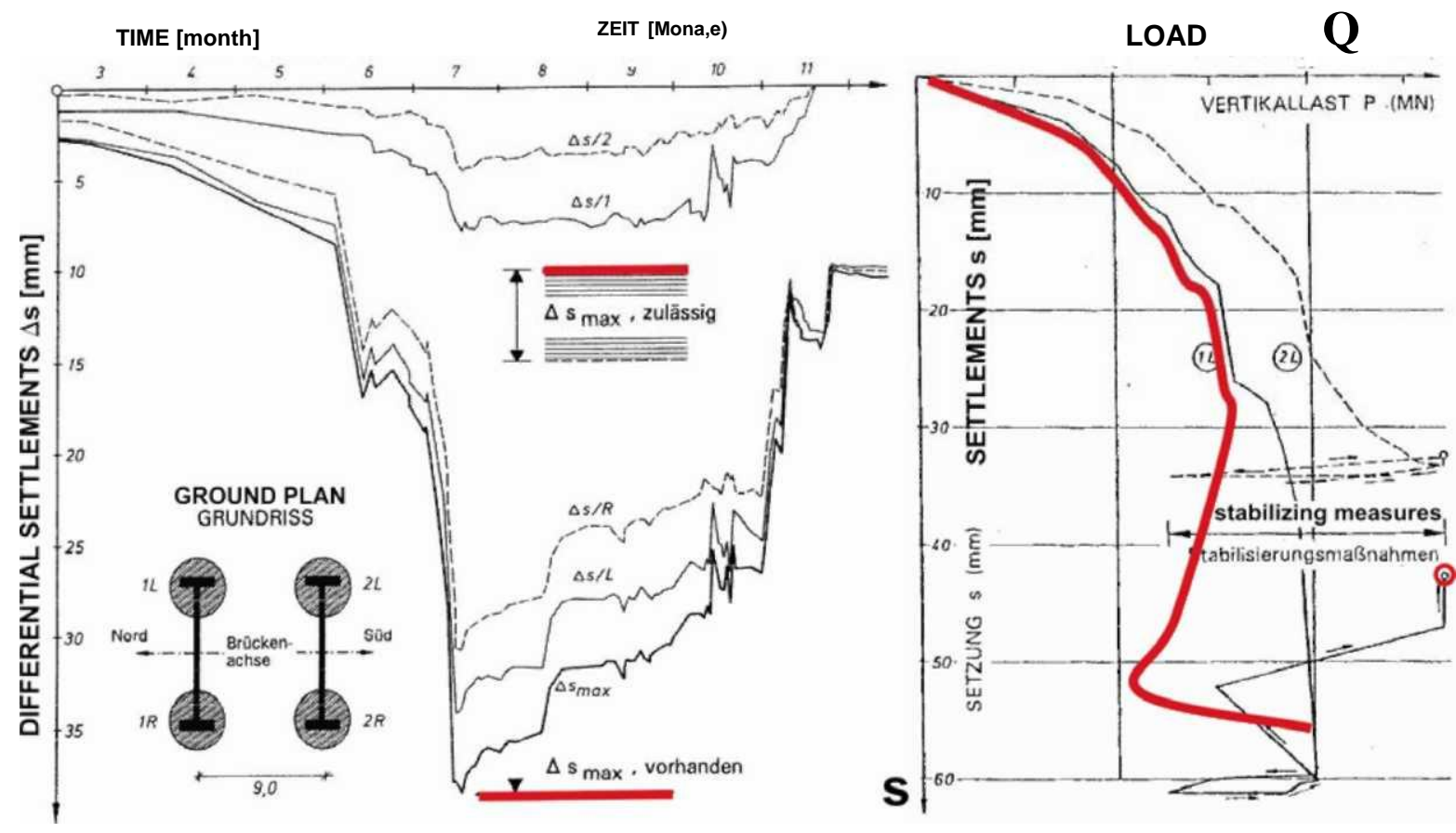

Figure 9 - Main pier of a $1.1 \mathrm{~km}$ long highway bridge close to collapse. Allowable differential settlement $\mathrm{As}_{\max }$, zulässig among the four foundation sockets of the twin pier were exceeded by $350 \%$ (red). Load-settlement curve of two sockets theoretically already in the state of "failure". Successful re-tilting (Brandl, 1991)

Not the price and fancy juridical agreements should be in the centre of negotiations, but the product, the "engineered building". Not the lawyer's but the engineer's word should carry the most weight.

The daily work of civil/geotechnical engineering has been done under increasing time pressure. Nevertheless, the attitude "Better to offer a poorly conceived design or calculation than to be too late" contradicts professional ethics (and may cause severe failures if supervisory control is missing). This refers also to tendering and following claims. 
A lowest price tender that is significantly lower than its nearest competitor bid should be excluded. "Value engineering" is a great concept potentially saving huge sums in construction costs, and in many cases, providing improved, safer design. (Osterberg, 1999). "Value engineering" in the interest of the engineers' employer or client could be achieved if engineers (or other geotechnical professionals) followed the old rule of thumb: "How would I do it if I were paying for it?"

In many cases, ethics is only based on rhetoric and good intentions. Engineering societies have traditionally treated questions of professional obligation under the rubric of "engineering ethics". But how is it possible to move beyond platitudes? Should young engineers be prepared to abandon their careers rather than abdicate their moral responsibility? Should engineers have an ethical obligation not do be involved with weaponry not to work in the defence industry, etc.

The endeavour to come up with a uniform code of ethics that might be endorsed by all the major professional societies is decades old - and the search for virtues that nobody can define. In the end, each individual is accountable to an inner moral code, to his inner conscience. The Austrian philosopher Arthur Schopenhauer (1788-1860) once stated in his pessimistic-ironical manner: "Ethics can as little help to become virtuous, as comprehensive aesthetics can teach how to create real works of art."

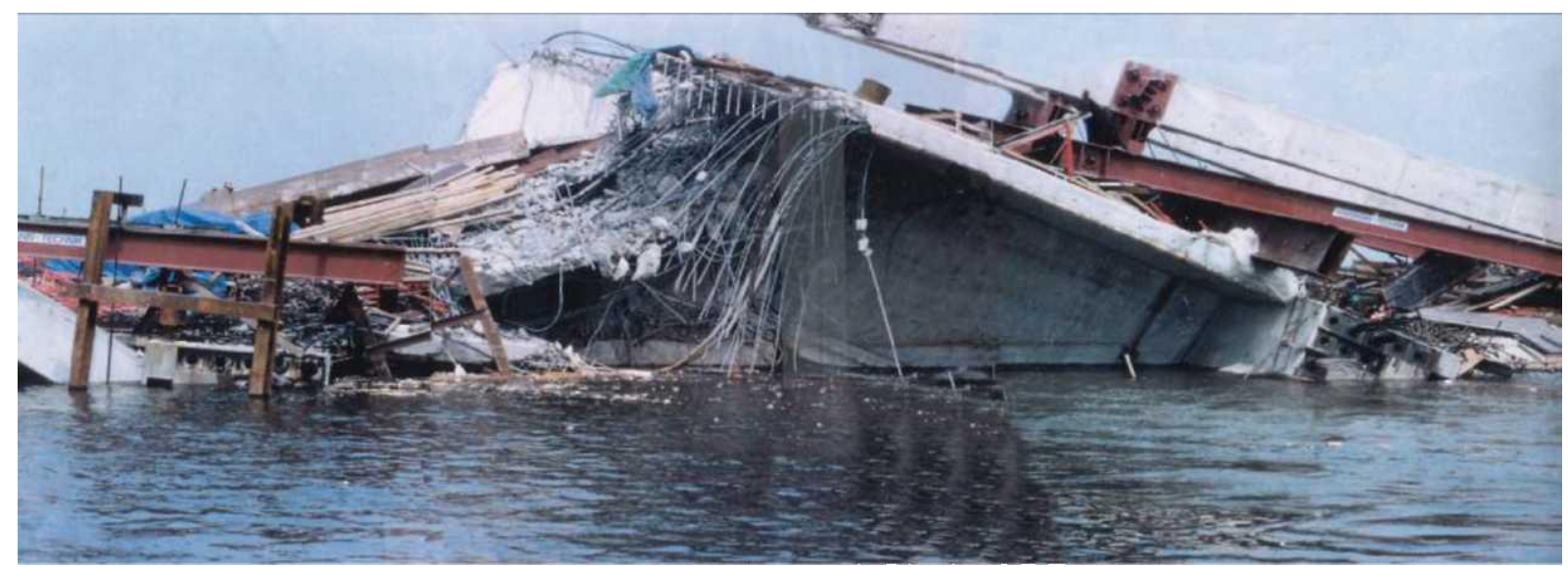

Figure 10 - Collapse of a bridge due to lacking control of the specific ground properties during pile execution (no comparison of design assumptions and locally found soil)

Morality cannot be achieved by making noble-sounding proclamations. The morality we seek should be founded in the real world and be capable of practical application. It should be able to meet standards of both good will and good sense (Florman 1987).

Comprehensive statistical investigations of structural failures disclosed that insufficient knowledge has been the dominating type of human unreliability (followed by underestimation of influence, carelessness and error) e.g. Figure 11. Most of the mistakes could have been detected in time by additional supervisory control. Consequently, the great need in engineering ethics is an increased emphasis on competence. Additional words are: dedication, energy, self-discipline, caution, alertness, awareness - and most of all conscientiousness. "The greatest threats to moral engineering are carelessness, sloppiness, laziness, and lack of concentration. An engineer may start out honest and high-minded but become immoral by falling prey to one or more of theses sins. On the other hand, an engineer who starts out by being conscientious must end up by being honest, since competent engineering, excellent engineering, is in its very nature the pursuit of truth. A conscientious engineer, by definition, cannot falsify test reports or intentionally overlook questionable data, cannot in any way evade the facts" (Florman 1987).

Ethics also means also humility and modesty, hence virtues that construction often has been lacking in the past decades. This is not inevitably the fault of architects and still less of civil or geotechnical engineers, but rather that of clients. Frequently, such "outstanding" projects or designs are determined by a tendency towards most striking features, sensations, or gigantism (megalomania), with display patterns and over-ambition being the driving forces. Thus, numerous unnecessary "superlatives" have been created. 
Higher, longer, larger, deeper are the keywords of over-ambitious architecture and construction that approaches the limits of technical feasibility, the limits of what can be done and the limits what is sensible, rational, reasonable (Figure 12).

Sometimes ethical issues arise during an engineer's career regarding situations in which an engineer has a responsibility to blow the whistle. Consequently, ethics plays an important role in educating young engineers. It should help them when being faced with ethical dilemmas in the work environment.

Education in ethics is essential, because laws alone are insufficient to combat corruption. Laws are ineffective, for example, against acts that are not strictly illegal, that are committed, for example, in a socially and culturally tolerated zone that forms a gateway to dependencies. Therefore, the goal must be to define values such as incorruptibility and transparency as demands of the individual's conscience within the scope of professional ethics. Accordingly, several authorities and companies have started to use ethics awareness programs as a means of communicating ethical awareness to their employees.

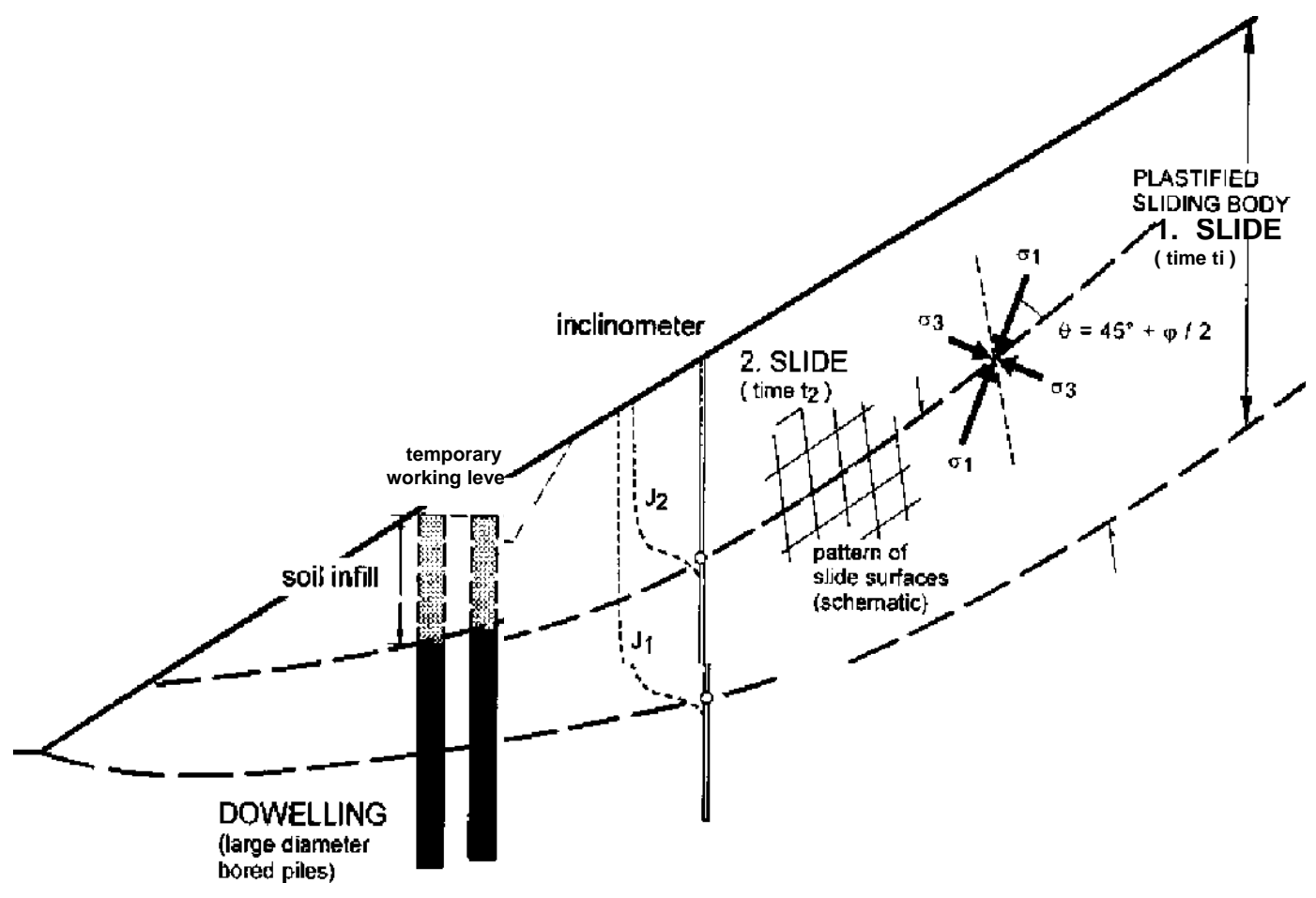

Figure 11 - Improper dowelling of sliding slope with bored piles which consisted of reinforced concrete only near the first slide zone. The refilling of the pile excavation above the initial slip only with soil allowed further slope failure due to a plastification of the whole slide body.

As far as the economical and ethical part of the profession is concerned, a saying by Thomas Mann (18751955) is highly recommended: "Enjoy your business activities during the day, but take on only such which let you sleep at night." Personal integrity and a clear conscience have always been an assurance for a good night's sleep. The historical statement of the Roman Emperor Vespasian (70 AD) "Pecunia non olet" ("money does not smell") is sometimes quoted to justify lack of ethics. But this is a total misinterpretation because the original statement was exclusively referring to the fees collected for the use of public toilets and can therefore not be applied generally.

Finally a comment that refers not only to our profession but also to industry and engineering as a whole, to the economy, commerce, the world of business, etc., and sometimes even to the sciences: A society which regards brutal competition as the essential principle of all human activities will in the end destroy itself, because it 
will have stopped to consider itself as a group that strives for and shares the same values and goals; it will become a "pool of sharks where everyone fights everyone else." Ethics should not be substituted by "monethics".

\section{Future prospects and challenges}

Civil engineering (geotechnical engineers commonly belong to this professional community) represents a highly interesting and always changing profession, which opens up for a variety of possibilities. In Germany, for instance, the building industry is still the biggest employer of industry, with hundreds of billions of Euro. About $80 \%$ of the national product -not including plots of land - are buildings, half of them apartments. The existing buildings have a value of trillions of Euro - and this substance can only be maintained with the help of civil engineers. Next to the building maintenance, the recycling processes and environmental problems represent the biggest chances for the future of civil engineers. The Austrian construction industry, for instance, shows by far the greatest potential for investment in the environmental sector, almost as high as mechanical engineering plus electrical engineering plus chemical and synthetic material industry put together.

In the European Community, about 30 million jobs depend directly on the building industry, which consequently is an important factor with regard to employment. Geotechnical engineering represents a key part of all building activities and of environmental protection worldwide.

In Europe and indeed globally, society faces unprecedented economic conditions, and at the same time, the world faces unprecedented environmental conditions. The imperative today is to deliver more for less: it is now crucial that civil engineers and the construction industry show that they can deliver "value for money". Additionally, civil engineers must also show how they deliver "value for carbon". This means that civil engineers have conflicting pressures: as well as the urgent need to reduce costs, there is another imperative - to reduce the carbon embodied in or used on the infrastructure they create (Hansford, 2011).

Design, construction, operation, maintenance and restoration of water supply and sewer systems in the rapidly growing mega-cities becomes an increasing challenge to civil engineering and especially to geotechnical engineering. Novel technologies for upgrading sewage systems with minimal disruption to surface activities are also required to prevent polluting sewer discharges.

Drinking-water supply, sewage removal/treatment and waste disposal are essential elements of prophylactic medicine. Therefore, civil and geotechnical engineers are challenged to develop proper sewage and waste disposal systems in time to prevent serious outbreaks of communicable diseases.

The move into the next decades and the expected growth in transportation require an efficient and highperforming infrastructure all over the world. Safety and high-traffic flow is important, and any restrictions due to reconstruction and maintenance should be kept at a minimum.

Transportation infrastructure is widely influenced by the location of industry, local density of population and political decision, and - from an overall point of view - less by geotechnical aspects. This is a great challenge to our profession because good ground (high quality "greenland") for new buildings becomes increasingly rare in the densely populated zones of the world, but size and sensitiveness of buildings have increased. It will become more and more necessary to construct in such weak soils, unstable areas and seismic zones, which formerly could be avoided. Consequently, civil/geotechnical engineers are forced to present solutions, which often reach the border of feasibility. This refers not only to alignments and buildings of infrastructure but is generally valid.

In detail, therefore, geotechnical engineering has a great influence on the alignment, design, construction and maintenance of all "traffic and transportation arteries". Geotechnics facilitates the individual traffic, the supply of modern society with goods and the disposal of the resulting waste and sewage via roads, highways, railways, subways, harbours and waterways, airports, pipelines, water supply and sewerage systems, etc. (including tunnels and pipes, galleries, bridges, retaining structures, landslide stabilization, ground improvement, etc.).

Civil engineering enables the increasing 24 hour - traffic and transportation in urban areas by innovative technology. For instance, special road concrete makes complete road repair and re-use by heavy traffic/transportation possible within 12 hours.

Environmental protection from traffic routes gains increasing importance: Not only noise barriers but also barriers against groundwater contamination. Precipitation washes heavy metals and mineral oil hydrocarbons from road surfaces into the ground. In case of heavy traffic and groundwater protecting zones special liner systems are required. 
Flood protection along rivers and coastal regions is a further challenge - especially considering the increase in number and magnitude of floods, and a rising sea level caused by a change in global climate. The design, construction and maintenance of safe dikes and dams, and their defense during catastrophic events, requires mainly the skills of civil/geotechnical engineers.

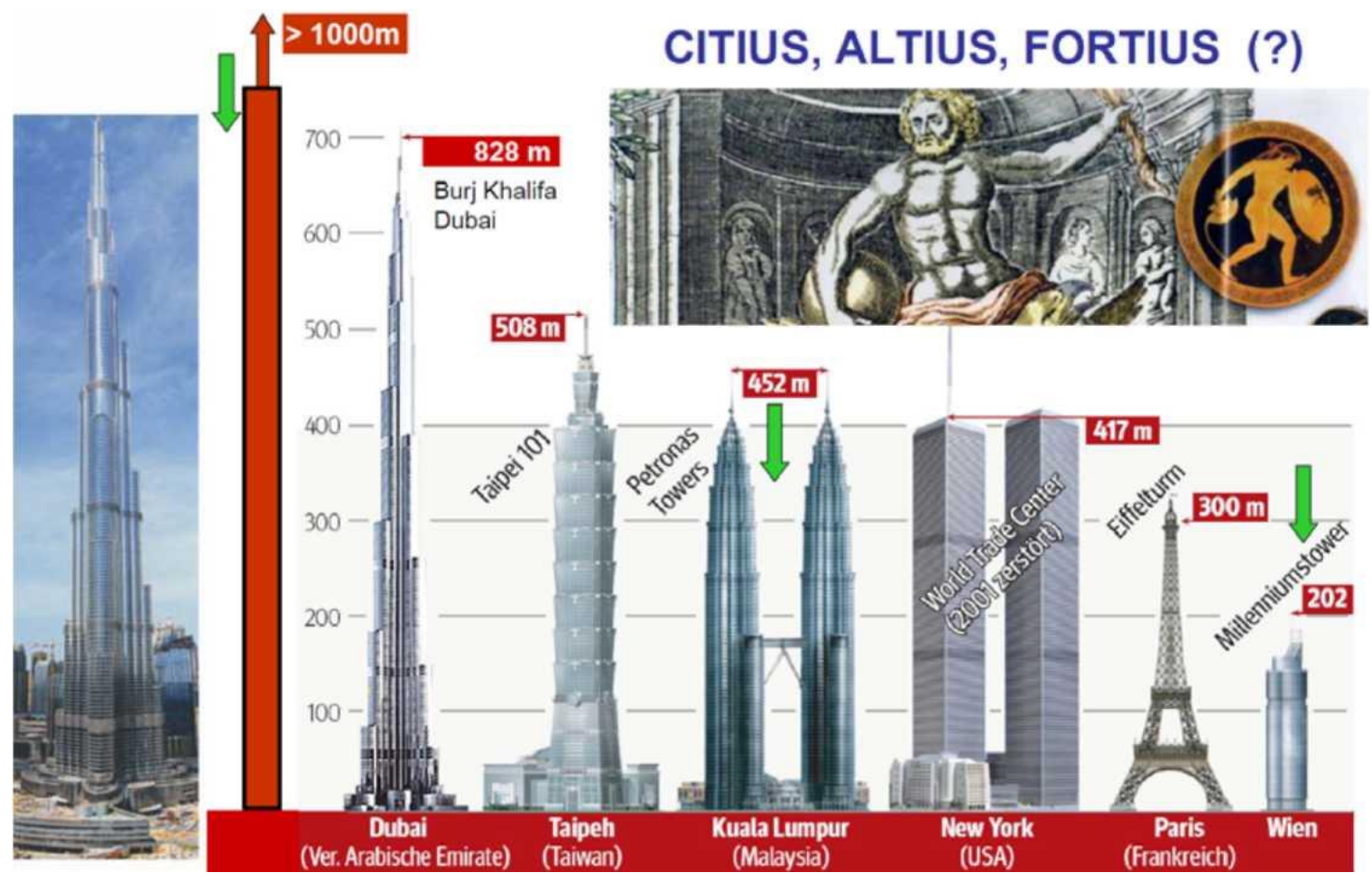

Figure 12 - Gigantism of high-rise buildings

Land reclaiming, especially in densely populated coastal regions is another challenge to civil engineering. The Kansai International Airport in the Bay of Osaka (hitherto the world's largest man-made island), the Hongkong Airport Check-Lap-Kok or Singapore's ambitious land reclaiming activities are outstanding examples of these activities.

Furthermore, geotechnical engineering could contribute essentially to a safety increase of tailings dams. Tailings impoundments are among the largest man-made structures with several of them approaching a billion tonne of stored sludge, sands, etc. Failures may therefore have a huge impact on the environment - and until recently they occurred at an unacceptable rate: at least ten times higher than those for conventional embankment dams (Davies et al. 2000). The dam failure in Kolontar/Hungary in autumn 2010 illustrates, that the safety situation or risk management resp. has hardly improved. Consequently, though tailings dams are only a cost to the mining process without generating a revenue like hydroelectric dams an increased awareness and emphasis on safety of tailings basins should be developed.

The rise in world population and living standard requires more and more energy. Hence the up-rating and refurbishment of existing power plants and the design and construction of new power plants are required. Small hydro projects are a valuable supplement to large-scale projects, and they save not-renewable natural resources like oil and reduce environmental impacts (air pollution). Small hydros certainly have a great future in the renewable-industry.

With the rapid economic and industrial growth of many regions, the development of water resources has become a vital element of the infrastructure to satisfy the increasing demand for energy, irrigation and drinking water supply. This development includes both, the construction of new facilities and the refurbishment of existing older plants.

Waste management (especially landfill engineering), the redevelopment of vacant or derelict land and contaminated site clearing represent additional geotechnical challenges. In this connection landfill mining should 
be mentioned as a promising waste management tool which simultaneously provides site remediation. This is a procedure whereby solid wastes which had previously been landfilled are excavated and processed to recover potentially useful materials including energy by incineration.

The combination of waste management and sustainable construction is another increasing challenge to civil engineering: For instance, the use of recycled concrete aggregates, exploiting wastes in concrete, the use fly ash and other residual (pre-treated or stabilized) wastes for embankments, roads and liner systems, etc. The conversion of waste and industrial by-products into beneficial products in the construction industry and the utilization of alternative construction materials as a substitute for primary materials provide advantages not only for the environment but also for civil engineering activities.
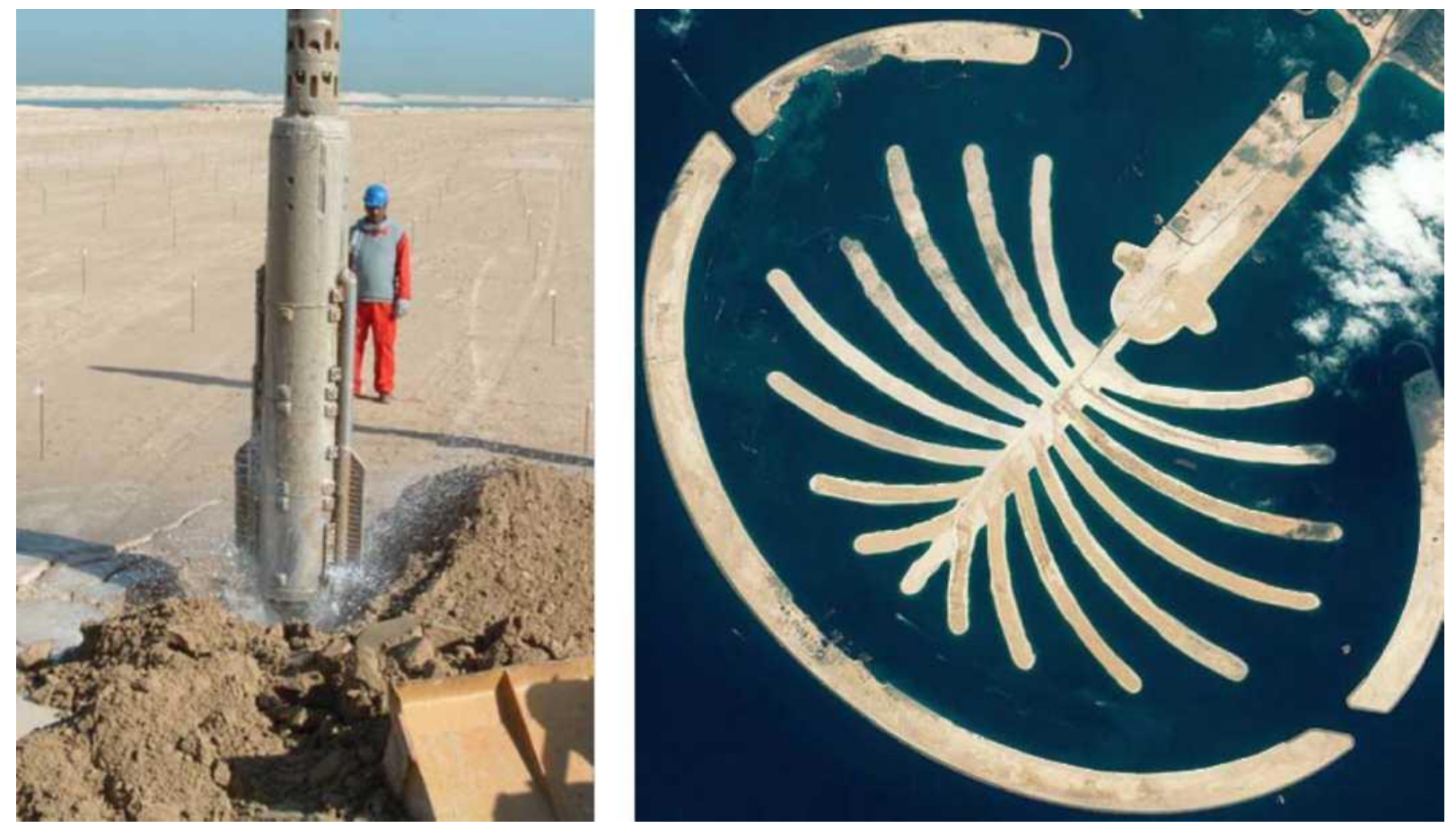

Figure 13 - Example for the contribution of geotechnical engineering to land reclaiming (Dubai)

Waste management covers only a specific topic of environmental issues. The more comprehensive field is resources management, which involves raw materials, recycled materials as well as waste. Consequently, resources management has been included nearly for 20 years in civil engineering education and training act the Technical University of Vienna.

As far as site cleaning, contaminated land remediation, upgrading open old dumps to safe landfills, construction, operation and aftercare/monitoring of new waste disposal facilities, etc. is concerned; a geotechnical/civil engineer is surely more qualified to give a profound judgment than a so-called "environmental engineer". This European experience was also confirmed by Jan Hellings (2000): "A trained civil/ground engineer is the best equipped to manage remediation projects and liaise with all the specialist advisers from allied professions."

The rather imprecise and elastic term "environmental engineer" is increasingly used by politicians and in the public because it sounds so competent. But actually it can hardly be considered a special branch of studies with in-depth education, research and knowledge in specific fields. Commonly it is rather an encyclopaedic mixture referring to biology, chemistry, civil engineering (including geotechnics), geology, hydrology, mechanical engineering, etc., whereby - as lies in the nature of such things - none of them are covered in real depth. Civil/geotechnical engineers, on the other hand, are specifically trained (or should be educated and trained!) for siting, contaminated land remediation, landfill engineering, waste and resources management, etc. A promising branch is geoenvironmental engineering as a combination of geotechnical and environmental engineering. To 
sum up, for a particular project, close co-operation of real (high-level) experts with specialized knowledge from different, relevant fields is most of the time more efficient than activities of so-called environmental engineers.
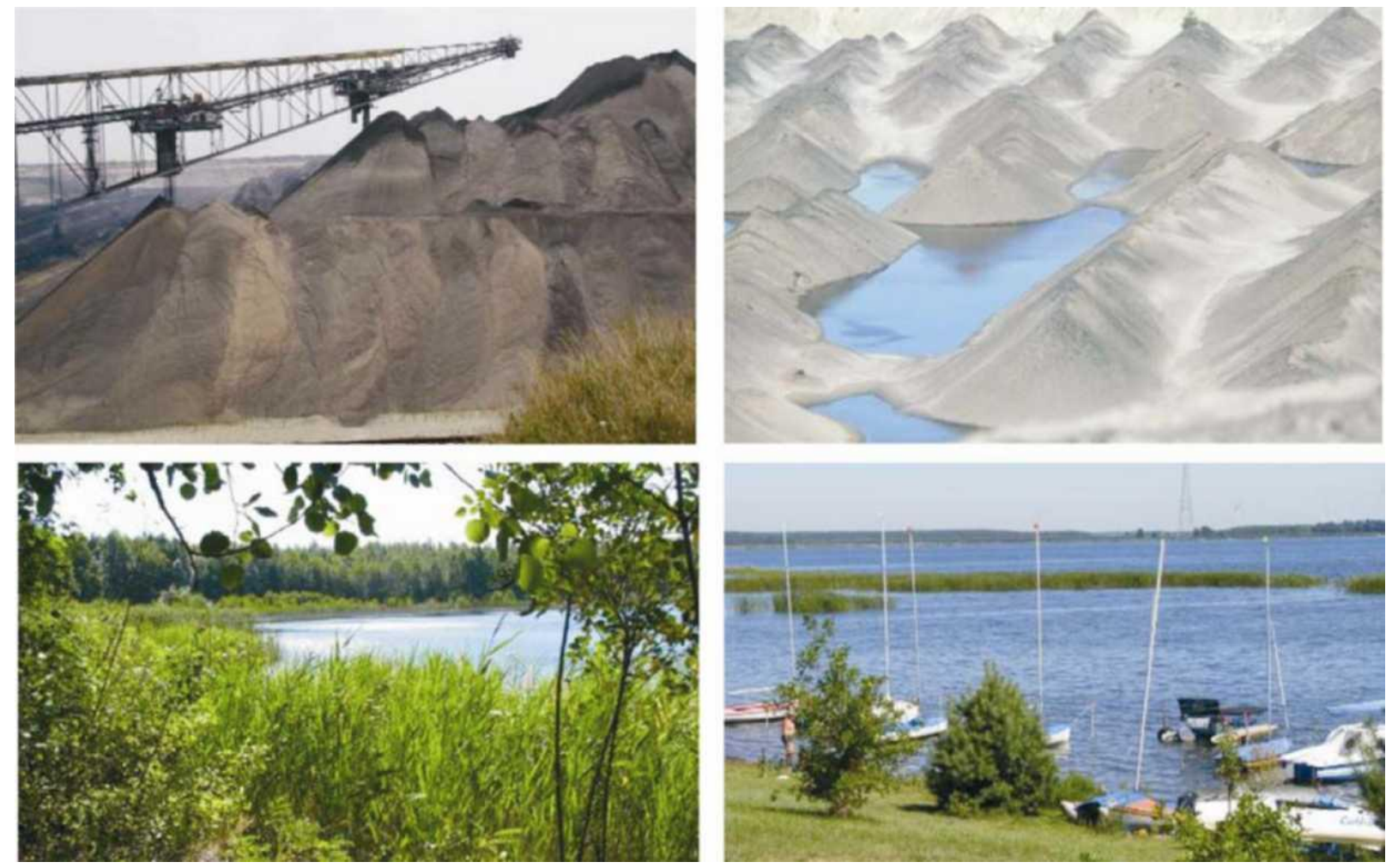

Figure 14 - Examples underlining the contribution of geotechnical engineering to renaturation (mining area Lausitz/Germany; photographs L. Wichter). Left/top: open pit mining under operation. Right/top: ecologically dead landscape after closing the mining activities. Below: after renaturation

Meeting the needs of an ever increasingly thirsty world is another challenge for civil and geotechnical engineering - in cooperation with agricultural engineering, etc. Only about $10 \%$ of the global water consumption by mankind is used for domestic water supply; $20 \%$ are consumed by industry and $70 \%$ by agriculture. The area of irrigated land worldwide has increased more than thirtyfold in the past two centuries, turning near-deserts such as southern California and Egypt into food baskets. Artificial oasis cities have bloomed.

Another great long-term challenge which geotechnical engineers are going to face within the next decades is an enormous increase in tunnelling and underground work under all soil and rock conditions, especially in urban areas. It is estimated that by the year 2025 at least 100 mega-cities, each with a population of between 5 to 30 million, will exist, and the urbanization of the world will further increase. This requires huge amounts of different underground structures, especially tunnels. Already now the traffic tunnels in Western Europe alone have a total length of more than $10,000 \mathrm{~km}$, which is four times the distance between Paris and Moscow.

Underground storage facilities are also increasingly needed. This requires not only new underground openings but could also make use of abandoned mines.

The following list gives an overview of important issues that represent key challenges to civil engineering, hence also to geotechnics. This list cannot be complete, nor does it show the individual concerns in any specific order of priority:

- Traffic and transportation infrastructure (construction and maintenance)

- Water management

- Resources management

- Waste management (solid and liquid)

- Hazard mitigation and prevention

- River management 
- Power generation

- Irrigation systems

- Urban and industrial ecology

- Land reclaiming (Figure 13)

- Abandoned and contaminated land remediation

- Renaturation of mining areas (Figure 14)

- Environmentally sound subsurface construction technologies

- Maritime engineering, involving port, harbour, estuarine, coastal and offshore engineering.

\section{References}

[1] Asmal, K. (2000). To dam or not to dam? World commission on Dams. International Water Power\& Dam Construction, July Issue.

[2] Atchison, P. (2002). Talking Point. Ground Engineering, Vol. 35, No. 7.

[3] Brandl, H. (1979). Design of high, flexible retaining structures in steeply inclined, unstable slopes. Proc. 7th European Conference on Soil Mechanics and Foundation Engineering. Brighton.

[4] Brandl, H. (1983). 100 Jahre Prof. Dr. Dr.h.c.mult. Karl v. Terzaghi. Heft 2 der Mitteilungen für Grundbau, Bodenmechanik und Felsbau. Technische Universität Wien.

[5] Brandl, H. (1990). Die Fußverstärkung einer 200 m hohen Talsperre. Konferenz "Geotechnische Probleme beim Bau von Kraftwerken". Vysoké Tatry, Slovakia.

[6] Brandl, H. (1991). Stabilization of excessively settling bridge piers. 10 $10^{\text {th }}$ European Conference on Soil Mechanics and Foundation Engineering, Firenze/ltaly, Proceedings Vol. 1.

[7] Burland, J.B. (1987). The Teaching of Soil Mechanics - A Personal View - The Nash Lecture. Proc. 9th European Conference on Soil Mech. and Found. Eng., Dublin, Ireland, Vol. 3.

[8] Clayton, C.R.I. (2000). Money can't buy risk-free ground. Ground Eng., Vol. 33, No.5.

[9] Clayton, C.R.I. (2001). Managing geotechnical risk. Thomas Telford Publishing, London.

[10] Davies, M. et al. (2000). Tailings Dams 2000. International Water Power \& Dam construction, May Issue.

[11] Dunnicliff, J. (2000). Ratings war. Ground Engineering, Vol. 33, No. 3.

[12] Florman, S.C. (1987). The Civilized Engineer. St. Martin's Griffin, New York.

[13] Hansford, P. (2011). Delivering value. Presidential Address. Proceedings of the Institution of Civil Engineers Civil Engineering 164, No CEI (London).

[14] Hellings, J. (2000). Your Career. New Civil Engineer, January Issue.

[15] Langdon, N. (2002). Talking Point. Ground Engineering, Vol. 35, No.11.

[16] Nichols, R.W. (2000). Risk. The Sciences. New York Academy of Sciences, May/June Issue.

[17] Osterberg, J. (1999). Value Engineering - a great concept. Ohio River Valley Soils Seminar.

[18] Peck, R.; Powderham, A. (1999). Talking point - The Observational Method. Ground Engineering, Vol. 32, No. 2.

[19] Powderham, A.J. (2002). The observational method - learning from projects. Proceedings of the Institution of Civil Engineers, Geotechnical Engineering 155, January Issue.

[20] Poulos, H. (2003). Deep foundations - can further research assist practice? 4th Int. Geotechnical Seminar "Deep Foundations on Bored and Auger Piles." Ghent University, Belgium.

[21] Rankilor, P. (1999). Talking point. Ground Engineering, Vol. 32, No 10. 